Araștırma Makalesi - Gönderim Tarihi: 21.02.2019 - Kabul Tarihi: 30.04.2019

\title{
Sosyal Medya Kullanımının Bir Belirleyicisi Olarak Narsisizm: Konya'da Yașayan Kullanıcılar Üzerine Bir İnceleme
}

\author{
Șükrü Balcı ${ }^{1}$ \\ Hamide Sarıtaș ${ }^{2}$
}

\begin{abstract}
Öz
İletişim alanında yaşanan teknolojik gelişimin bir sonucu olarak hayatımıza giren sosyal medya; insanlara eğlendirme, vakit geçirme, sevdikleriyle iletişim kurma ve bilgiye ulaşma imkânı vermektedir. Sosyal medya kullanımı, bireylerin isteklerini, arzularını ve sorunlarını ifade etmelerine; başarılarını potansiyel olarak geniş bir izleyici kitlesine göstermelerine ve diğer sosyal medya kullanıcılarından beğenme ve olumlu yorumlar almalarına ve son tahlilde yüksek oranda tanınma elde etmelerine olanak sağladığı için anlamlı görünmektedir. Bu noktada narsisizm eğilimi olan insanlar; kendi kendilerini tanıtmaları üzerinde tam kontrol sahibi oldukları için, sığ ilişkilerden oluşan çevrimiçi toplulukları tercih ederler. İşte bu araştırma kullanıcıların narsisizm özelliklerinin sosyal medya kullanımı üzerindeki etkinliğini konu edinmektedir. Araştırma için veriler 408 katılımcıdan yüz yüze görüşme yoluyla elde edilmiştir. Araştırma sonucunda; narsisizm düzeyinin, sosyal medya kullanım puanını anlamlı biçimde yordadığı tespit edilmiştir. Katılımcıların narsisizm düzeyleri arttıkça, sosyal medya kullanım amaç ve isteklerinde de bir artış yaşanmaktadır. Yine çalışmada günlük sosyal medya kullanım süresi ile narsisizm arasında anlamlı korelasyon ortaya konulmuştur.
\end{abstract}

Anahtar Kelimeler: Narsisizm, sosyal medya, ilişki, saha araştırması

Atıf: Balcı, Ș. Ve Sarıtaș, H. (2019). “Sosyal Medya Kullanımının Bir Belirleyicisi Olarak Narsisizm: Konya’da Yașayan Kullanıcılar Üzzerine Bir İnceleme”. Akdeniz Üniversitesi Illetișim Fakültesi Dergisi, (AKiL) Haziran (31), s. 689-709 1 Prof. Dr., Selçuk Üniversitesi İletişim Fakültesi, Gazetecilik Bölümü, sukrubalci@selcuk.edu.tr,
ORCID: 0000-0002-0477-0622

2 Selçuk Üniversitesi Sosyal Bilimler Enstitüsü, Gazetecilik Anabilim Dalı Doktora Öğrencisi, hsarıtas32@ gmail.com, ORCID: 0000-0003-1401-4174 


\title{
Narcissism as Predictor of Social Media Use: A Study on Living Users in Konya
}

\begin{abstract}
Social media which have entered our lives as a result of technological development in the field of communication gives people the opportunity to entertain, spend time, communicate with their loved ones and reach information. Use of social media means that individuals express their wishes, desires and problems; it seems to be meaningful because it enables them to show their success to a large audience and to like and appreciate other social media users and get a high level of recognition. At this point, people with a tendency to narcissis prefer online communities of superficial relationships, as they have full control over their self-introduction. This research focuses on the effectiveness of the narcissistic features of users on social media usage. The data for the study were obtained through face-to-face interviews from 408 participants. As a result of the research; it was determined that the level of narcissism significantly predicted social media usage score. As the narcissism levels of the participants increased, there was an increase in the use and desire of social media. In the study, a significant correlation was found between daily social media usage and narcissism.
\end{abstract}

Keywords: Narcissism, social media, relationship, survey

\section{Giriș}

Y eni iletişim teknolojileri artık bireylerin tüm yaşam pratiklerinde yer almaktadır. Özellikle sosyal medya ağları, bireylere birçok iletişim kanalını kullanarak farklı nitelikte, iletişim ve etkileşim içine girebilecekleri, çok yönlü sanal topluluk oluşturma imkânı sunmaktadır (Kuşay, 2013: s.1).

İnternet teknolojisinin gelişmesi ve yaygınlaşmasıyla bireyler çok fazla imkâna sahip olmuşlardır. Özellikle iletişim teknolojisinin gelişmesiyle birlikte bireyler çok kısa zamanda çok fazla kişi ile iletişim kurma imkânına sahip olmuştur. Bunun yanında Web 2.0 teknolojisinin gelişimiyle birlikte sanal iletişim interaktif bir boyut kazanmış ve iletişim için gerekli olan aynı zamanda ve aynı yerde olmak gerekliliği ortadan kalkmıştır. Ayrıca mobil iletişimin yaygınlaşıp, akıllı cihazların sosyal medyayı kullanma olanağı sunması sayesinde sosyal medya ağları çok popüler bir platform haline dönüşmüştür (Oğuz, 2016: s.52).

Daha çok gençlerin yoğun bir şekilde kullandığı sosyal medya ağları kullanıcıların, bireysel ve herkese açık profiller oluşturabileceği, gerçek hayattaki arkadaşlarıyla etkileşimde bulunabileceği ve paylaşılan ilgi alanlarına göre diğer insanlarla tanışabileceği sanal topluluk platformlarıdır (Wilson vd., 2010: s.173). Dolayısıyla artık pek çok kişi sosyal medya kullanıcısıdır ve bu kişilerden çoğu günlük olarak bu platformlarda çevrim içi vakit geçirmekte, yazı, fotoğraf veya video paylaşabilmekte sanal arkadaşlarıyla iletişim kurabilmektedir (Alanka ve Cezik, 2016: s.550). 
Sosyal medyanın sağlamış olduğu interaktiflik özelliği sayesinde artık milyarlarca kişi, zamanını hem sosyal ağlarda içerik oluşturarak; hem de söz konusu içeriği tüketerek geçirmektedir. Sosyal medya kişilerin kendilerini ifade etmesini kolaylaştırmaktadır. Özellikle sosyal medyanın kullanıcılara içerik üretme imkânı vermesi, kişilerin üretmiş oldukları içerikleri başkalarına da gösterme imkânı bulmaları onların narsistik kişilik özelliklerinin artmasına neden olmaktadır. Sosyal medyanın popülerliği ve bireylere sağlamış olduğu görece serbestliği bireylerin kişilik özelliklerini sergilemek için sosyal medyayı oldukça uygun bir alan haline getirmektedir (Oğuz, 2016: s.52).

Sosyal medyada narsisistik davranış, bireylerin sıklıkla "özçekimler" gibi sergiledikleri çeşitli "kendini teşvik etme" davranışlarıyla ön plana çıkmaktadır. Bunlarla, bireyler başkalarından onaylama ve ilgi arıyor olabilmektedirler. Narsistler yaygın bir sosyal onay hissi duymaktan hoşlanmakta; sosyal ağlar da onların bu duruma ulaştıklarına inanmalarını sağlamaktadır. Sosyal medya, özellikle gençlerin yüzlerce ya da binlerce "arkadaşı" olduğunu düşündürerek kendilerini kandırmalarına izin verebilmektedir (Nevils ve Massie, 2014: s.4).

Sosyal medya kullanımı ve narsisizm konusunu ele alan akademik çalışmalar incelendiğinde, araştırmaların odaklandıkları soruların; kişilerin sosyal medya kullanıcısı olma olmama durumlarının narsisizmle olan ilişkisi; sosyal medya kullanımında narsisizmle ilişkilendirilen unsurların neler olduğu; sosyal medya kullanım sıklığı ile narsisizm arasındaki bağlantı; sosyal ağlarda narsisizmin nasıl ifade edildiği (Alemdar vd., 2017: s.73) ve sosyal medyanın narsist eğilimler üzerindeki etkisi (Malik ve Khan, 2015) yönünde olduğu görülmektedir. Bazı araştırmalar narsisizm ile sosyal ağ kullanımı arasındaki pozitif ilişkiye vurgu yaparken (Buffardi ve Campbell, 2008; Wang vd., 2012; Panek vd., 2013; Fox ve Rooney, 2015); diğerleri (Skues vd., 2012) ise bir ilişkinin varlığını ortaya koyamamaktadır.

Bireylerin narsisizm, benlik saygısı ve yalnızlık gibi psikolojik durumları; onların sosyal medyadaki davranışlarını etkileyen önemli faktörler olarak da ön plana çıkmaktadır (Marshall vd., 2015; Leung, 2013; Kuss ve Griffiths, 2011; Correa vd., 2010). Daha yüksek narsisizm seviyesine sahip kullanıcılar; sosyal medyada daha fazla sayıda arkadaşa sahip olma, daha fazla duvar yazısı ve fotoğraf güncellemesi yapabilme eğilimindedir (Poon ve Leung, 2011; Ong vd., 2011; Mo ve Leung, 2015).

Iş̧te Konya merkezde yaşayan 18-65 yaş arasında ve farklı meslek gruplarından sosyal medya kullanıcılarının örneklem olarak seçildiği bu araştırmada; bireylerin sahip oldukları narsistik karakter özellikleri ile sosyal medya kullanımları arasındaki ilişkinin ortaya konulması amaçlanmaktadır. Bu amaç doğrultusun katılımcılardan veriler toplanmış ve değerlendirilmiştir.

\section{Narsisizm}

Sözlük anlamı özseverlik olan narsisizm, kişinin kendi bedensel ve ruhsal benliğine karşı hayranlık ve bağlılık duymasıdır (www.tdk.gov.tr). Narsisizm, kelime kökeni olarak 
Yunan mitolojisine dayanmaktadır (Çakmak, 2018: s.137). Mitoloji sözlüğüne göre bu kavram, suda kendi yansımasını gören ve ona aşık olan Narkissos'dan (Narkissos Efsanesi) gelmektedir (aktaran, Alemdar vd., 2017: s.74).

Narsisizm etimolojik olarak narke (duyarsızlık) sözcüğü ile ilişkilendirilir. Bu bağlamda bakıldığında narsisizm, benlik hakkında aşırı olumlu ve abartılı düşünceye sahip olunmasının yanında kibirlilik, benmerkezcilik, kendini beğenmişlik, gösterişçilik gibi davranışlara da karşılık gelmektedir (Twenge ve Campbell, 2015; aktaran; Uçar ve Konal, 2018: s.94). Narsisizm aynı zamanda kişinin kendini gösterişli ve kibirli bir şekilde kabul etmesi anlamına da geldiği görülmektedir (Gençtan, 2010: s.19).

Narsisizm kavramı psikoloji disiplininde ilk kez 1885 yılında Havelock Ellis kullanmıştır. Yazar kavramı; "cinsel duyuların kendine hayranlık içinde anlatımı" olarak ele almıştır (Ellis, 1898; aktaran, Raskin ve Terry, 1988: s.890). Narsisizm kavramı 1899 yılında Paul Nacke ile ilk kez psikiyatri alanına girmiştir. Nacke narsisizmi, kendi bedenine cinsel bir nesnenin bedenine davrandığı gibi davranan, kendi bedenine tam bir tatmin elde edene kadar bakan, dokunan, okşayan birinin durumunu tanımlamak olarak ifada etmiştir (Raskin ve Terry, 1988: s.890). Ellis ve Nacke'den farklı olarak Freud (1998: s.23) narsisizmi, kişinin kendini koruma içgüdüsünden kaynaklanan bencilliğin libidinal bir tamamlayıcısı olarak görmüş ve narsisizm her canlı varlıkta bir ölçüde bulunabilecek bir durum olarak tanımlamıştır.

Freud narsisizmi psikanaliz olarak değerlendirmiş; özgüvenin değişik bir yönü olarak ele alıp, aynı zamanda bir gelişim mi? yoksa bir bozukluk mu olduğu yönünde araştırmalar yapılmasını sağlamıştır (Sandler vd., 2012). Bu doğrultuda Gençtan (2010) yaptığı "Psikodinamik Psikiyatri ve Normal Dışı Davranışlar" adlı araştırmasında; normal narsisizm ve patolojik narsisizm arasında bir ayrım bulunduğunu, insanın kendini beğenme ve değerli bulmasının normal, hatta gerekli bir duygu olduğunu ama bu duyguların abartıldığında kişilik bozukluğuna dönüşebileceğini ortaya koymuştur.

Narsisizm, alan yazında genelde psikiyatri ve psikoloji bilim dallarında daha çok inceleme konusu yapılmasına rağmen; kavram üzerine örgütsel davranış, yönetim alanları ve sosyal bilimler alanlarında da çalışılmıştır ve çalışılmaktadır. Sosyal bilimler alanında Türkiye'de örneğin iletişim (Gülnar vd., 2010; Ertürk ve Eray, 2016; Çakmak, 2018) ve eğitim (Ekşi, 2012; Uçar ve Konal, 2018) alanlarında çalışmalar yürütülmüştür.

\section{Narsisizm ve Sosyal Medya}

Sosyal ağlar Web 2.0 teknolojisi temeline dayanmakta ve kullanıcıya içerik üretme, değiş tokuş etme imkanı sunmaktadır (Kaplan ve Haenlein, 2010: s.61). Sosyal ağlar içerinde yer alan sosyal medya siteleri insanların birbirleriyle iletişim kurmalarını, içerik üretme, paylaşma ve yorum yapmalarını kolaylaştırmaktadır.

Sosyal paylaşım ağı olan sosyal medya kanalları son yıllarda insan hayatında önemli 
bir yer edinmiştir. Web 2.0 teknolojisi aracılığıyla iletişimin ve paylaşımın arttığı sanal dünya yüz yüze iletişimin gerekliliğini ortadan kaldırmaktadır. Bu yeni medya kanalları kullanıcılarının ya da kişilerin kendilerini istedikleri gibi tanımlayacakları yeni bir kimlik oluşturabileceği bir alan ve izlenebileceği bir ortam oluşturmaktadır. Bu nedenle kullanıcı sayısı sürekli artan sosyal medya sitelerinin etkilerinin araştırılması önem kazanmaktadır (Çakmak, 2018: s.145).

Özellikle internetin günlük hayatta yaygın bir şekilde kullanılmaya başlamasıyla 2004 yılında Facebook, 2010 yılında Instagram gibi dünyaca ünlü sosyal medya platformların piyasaya çıkması, iletişim ve paylaşım alanları beraberinde yeni anlayışlarda getirmiştir (Mehdizadeh, 2010: ss.357-358).

Dünya genelinde olduğu gibi Türkiye'de de giderek kullanımı ve dolayısıyla önemi artan sosyal medya, özellikle sosyal bilimler alanında yürütülen birçok araştırmaya konu olmaktadır. Sosyal medya kullanımının yaygınlaşmasıyla farklı psikolojik boyutlarda birlikte gelmektedir (Mehdizadeh, 2010). Bu bağlamda bakıldığında sosyal medya kullanımı üzerine yapılan araştırmalarda narsisizm, öz saygı, utangaçlık, benlik sunumu ve yalnızlık gibi boyutların ortaya çıktığı, sosyal medya kullanıcılarının; narsistik, fakat daha az vicdani ve sosyal olarak yalnız olma eğiliminde olduğu gösterilmiştir. Ayrıca, sosyal medya kullanım sıklığının ve belirli özellikler için tercihlerin, nevrotiklik, yalnızlık, utangaçlık ve narsisizm gibi bazı özelliklerin bir sonucu olarak değiştiği bulgulanmıştır (Ryan ve Xenos, 2011: s.1658). Bu boyutlardan en fazla dikkat çekici olanı ise "narsisizm" olarak tanımlanmaktadır (Mehdizadeh, 2010).

Narsisizmin en önemli özelliği, bireyin diğer bütün herkesten farklı olarak kendisini öne çıkarması ve başkalarına duyulan ilginin azalması durumu olarak ön plana çıkmaktadır (Timuroğlu ve İşcan, 2008: s.240). Bu durum sosyal medyada kişisel olarak tanıtımını yapan kişilerin, diğer sosyal medya kullanıcıları tarafından onay ve dikkat bekleyen, bunu sağlamak içinde öz çekim paylaşımı, durum ve yer paylaşımı, vb. paylaşımlarda bulunan kişilerin davranışları ile ilgili olmaktadır (Alemdar vd., 2017: s.74).

Narsisizm bireylerde normal ve patalojik olarak iki şekilde görülmektedir. Normal narsisizm, bireyin çevresine uyumlu ve çevresinin beklentilerini karşılayabilen, kendine değer veren, özgüveninin yüksek olması durumudur. Patalojik narsisizm ise bireyin kendinden emin, başkalarının düşüncelerini önemsemeyen, kendini aşırı sevme önemseme tavrı gösterme durumudur. Yani bireyin kendi benliğini aşırı abartması olarak da tanımlanmaktadır patolojik narsisizm. Bu nedenle patalojik narsisizm kategorisinde olan kişiler kendilerini aşırı beğenen, başkalarını küçümseyen, onları kontrol altında tutmaya çalışan, güce ve ilgiye aşırı derecede intiyaç duyan bireyler olarak kendilerini göstermektedirler (Özsoy ve Ardıç, 2017: ss.393-394).

Sosyal medya ve narsisizm arasındaki ilişkiyi ele alan çalışmaların odaklandığı noktaya bakıldığında; sosyal medya ile narsisizm davranışının nasıl artırıldığı (Buffardi ve Campbell, 2008), sosyal medya kullanım motivasyonları boyutu olarak narsisizm ele alınması (Alemdar ve Köker, 2013; Köseoğlu, 2012), farklı sosyal medya 
platformlarında narsisizmin rolünün keşfi (Davenport vd.,2014), narsisizmin sosyal medyada nasıl ifade edildiği şeklinde çeşitlilik göstermektedir (Alemdar vd., 2017: s.77).

Narsisizm ile sosyal medya kullanımı arasındaki ilişkiyi ortaya koymayı amaçlayan araştırmalar içerisinde örneğin Buffardi ve Campbell (2008), sosyal medya sitelerini aktif kullanan katılımcıların narsisizm davranışlarında daha fazla bulunduklarına vurgu yapmaktadır. Yazarlar çalışmalarında narsisizm ile sosyal medya kullanımı arasında pozitif yönde kolerasyon olduğunu bulgulamışlardır. Mehdizadeh (2010: s.357), York Üniversitesi'nde yaşları 18 ile 25 arasında 100 Facebook kullanıcısının Facebook web sayfası narsisizm ve benlik saygısı üzerinde araştırma gerçekleştirmiştir. Sonuçlara bakıldığında, narsisizm puanları yüksek bireylerin Facebookta daha çok aktif olduğunu ortaya koymuştur. Bu sonuç narsisizmin sosyal medya kullanımında önemli bir yordayıcı olduğunu göstermiştir.

Bergman ve arkadaşları (2011) araştırmalarında, narsisizm davranışı gösteren ve sosyal medyada arkadaş sayısı çok olan bireylerin sosyal medyayı, narsistik kişilik özelliğine sahip olmayan bireylerden daha fazla kullandıklarını bulgulamışlardır. Sosyal medyada var olan arkadaş sayısı ile narsisizm ilişkisinin anlamlı ve pozitif yönde olduğu ortaya konulmuştur. Bir diğer çalışmada da, örneklem olarak 18- 65 yaş arasında aktif olarak Facebook kullanan, kolej öğrencileri ve kadınlardan oluşan araştırmasında Facebook kullanımının narsisizm davranışının büyük yordayıcısı olduğu tespit edilmiştir (Carpenter, 2012).

Bir başka çalışmada narsisizm ve Facebook kullanım sıklığı arasında pozitif ilişki olduğu bulgulamıştır. Ayrıca Facebook'taki arkadaş sayısı ile narsisizm düzeyi arasında pozitif anlamlı bir ilişki bulunmaktadır (McKinney, vd., 2012). Yapılan bir başka araştırmada Facebook kullanımı ile narsisizm kişilik özelliği arasında pozitif ilişki olduğunu ortaya koymuşlardır (Pettijohn vd., 2012).

Leung'un (2013: s.997) yaptığı çalışmada sosyal medya kullanım motivasyonları ve narsistik kişiliklerdeki nesiller arasındaki farklılaşmayı ortaya koymak için 2010 yılında 596 sosyal medya kullanıcısı ile telefon aracılığıyla anket uygulanmıştır. Faktör analizi sonuçları insanların sosyal medyayı kullanarak beş sosyo-psikolojik ihtiyaçlarını karşıladığına işaret etmektedir. Bu ihtiyaçları; şefkat göstermek, havalandırma yapmak, olumsuz duygular, tanınma, eğlence ve bilişsel ihtiyaçların karşılanması oluşturmuştur. Katılımcıların hoşnutsuzluklarını gidermek istediklerinde blogları kullandıkları; olumsuz duygularını ifade etmek, teşhircilerin sosyal medyayı şefkat göstermek, olumsuz duygularını ifade etmek için kullandıkları sonucuna ulaşılmıştır. Aynı zamanda daha çok narsist olan internet kullanıcılarının sosyal medyayı daha sık kullandıkları sonucuna ulaşmıştır. Panek ve arkadaşları (2013) benzer sonuçlara ulaşmışlardır. Facebook'un durum gönderme sıklığı ile narsisizm seviyesinin pozitif ilişkili olduğu sonucunu bulgulanmıştır.

Abdullah ve arkadaşları (2014) yapmış oldukları çalışmada, narsisizm seviyesi 
yüksek olan bireylerin Facebook kullanım seviyelerinin yüksek olduğunu ortaya koymuştur. Diğer bir anlatımla narsisizm düzeyi ile Facebook kullanımı arasında pozitif ilişki ortaya konmuştur. Davenport ve arkadaşları (2014: s.218) Facebook ve Twitter gibi sosyal medya araçları kullanımı ile narsisizm ilişkisini ele aldıkları çalışma gerçekleştirmişlerdir. Araştırma sonuçlarına bakıldığında hem Facebook hem de Twitter kullanımında narsisizmin önemli bir yordayıcı olduğu ortaya çıkmıştır. Araştırmanın bir diğer sonucu ise Twitter kullanıcılarının Facebook kullanıcılarından daha çok narsistik özellik gösterdikleri olmuştur.

Diğer bir araştırmada Çin'de kentsel alanda yaşayan, narsistik özelliği taşıyan ergen bireylerin sosyal medyayı daha çok kullandıkları sonucuna ulaşılmıştır. Aynı zamanda kendini özümseme, sömürülebilirlik ve kendini üstün gösterme gibi özelliklerin sosyal medya kullanımı ile ilişkisi tespit edilmiştir (Huang, 2014).

Lee ve Kim (2014: s.166), bireylerin kişisel özellikleri ile Facebook'taki kişisel sunum arasındaki ilişkiyi ortaya koymayı amaçlayarak yaptıkları çalışmada Facebook kullanıcıları ile çevrimiçi anket uygulanmıştır. Araştırma sonucunda yazarlar, Facebook haber kaynağında ve durumlarda kendini sunma ve dışadönüklük arasında pozitif ilişki olduğu sonucuna ulaşmışlardır. Facebook duvar yazılarında güncellemede kendini sunma ve narsisizm arasında pozitif ilişki olduğu sonucuna varmışlardır. Winter ve arkadaşlarının (2014: s.199) yaptığı araştırmada sosyal medya sitelerinde yapılan durum güncellemeleri ile narsisizm davranışı arasında pozitif yönde ilişki olduğu sonucuna ulaşıImıştır. Yapılan durum güncellemelerinde narsisizmin önemli bir belirleyici olduğu sonucuna ulaşılmıştır.

Özçekim davranışı ile narsisizm davranışı arasındaki ilişkinin ölçülmesinin amaçlandığı bir çalışmada da, özçekim sıklığı ile narsisizm boyutları arasında pozitif korelasyon tespit edilmiştir (Barry vd., 2017: s.48).

ABD'de 18 - 40 yaş arası erkeklerinin örneklem alındığı çevrimiçi araştırmalarında kullanıcılarının göndermiş olduğu özçekim fotoğrafları ve kullanıcıların çekip gönderdiği fotoğraflar üzerinde narsisizm, piskopati üzerine incelemeler yapmışlardır. Araştırma sonucunda sosyal medya sitelerinde geçirilen zaman ile narsisizm seviyesinin artmasında önemli bir yordayıcı olarak bulgulanmıştır (Fox ve Rooney, 2015: ss.163164).

Mo ve Leung (2015: s.152) yapmış olduğu çalışmada da benzer sonuçlar ortaya çıkmıştır. Weibo sosyal medya sitesini daha çok narsisizm davranışına sahip olan bireylerin kullandığı belirlenmiştir. Weibo kullanım yoğunluğu artıkça, narsisizm davranışının da arttığı ortaya çıkmıştır.

Walters ve Horton (2015: s.326) gerçekleştirmiş oldukları araştırma, narsistik öz saygının Facebook kullanım sıklığını arttırdığını göstermektedir. Weiser'in (2015: s.477) yapmış olduğu araştırmada da sosyal medyada özçekim yapma sıklığı ile narsisizm arasında olumlu ilişki olduğu sonucuna ulaşılmıştır. 
Türkiye'de sosyal medya ve narsisizm ilişkisini ele alan alışmalar olarak; Ertürk ve Eray'ın (2016) “Fenomenolojik Bir Kavram Olarak Kendilik ve Sosyal Ağlarda Kendilik Sunumu ile Narsistik Eğilimler İlişkisi: İletişim Fakültesi (İ.Ü.I.F.) Öğrencileri Üzerine Bir Ön Çalışma”, Alanka ve Cezik’in (2016) “ Dijital Kibir: Sosyal Medyadaki Narsistik Ritüellere İlişkin Bir İnceleme”, Çakmak'ın (2018) "Online Benlik Sunumu ve Narsisizm Arasındaki İlişki: Üniversite Öğrencileri Üzerinde Bir Araştırma” başığı ıltında Aksaray Üniversitesindeki öğrencilerin benlik sunumu ve narsisizm davranışında Facebook sanal ortama ele alınmıştır.

Oğuz (2016) Facebook kullanıcılarının narsistik karakter özelliklerini nasıl yansıttıklarını saptamak için 218 Anadolu Üniversitesi öğrencisi arasından kolaylı örneklem tekniğini kullanarak örneklemin seçildiği bir araştırma yapmıştır. Araştırma sonucunda narsisizm boyutlarından özellikle otorite, teşhircilik ve üstünlük ile narsistik toplam puan arasında; Facebook'ta harcanan zaman ile narsistik toplam puan arasında, Facebook'ta sahip olunan arkadaş sayısı ile narsistik toplam puan arasında pozitif yönde bir ilişki bulunmuştur.

Gerek dünyada gerek Türkiye'de yapılan araştırmaların sonuçları incelendiğinde sosyal medya kullanımı ile narsisizm arasında pozitif ilişki olduğu sonucuna ulaşılmaktadır. Yapılan araştırmalar, kullanıcıların sosyal medyayı bir vitrin olarak kullandıkları ve burada kendilerinin en güzel, en etkili ve en dikkat çekici yönlerini sergilemek için sosyal medyaya yöneldiklerini ortaya koymaktadır. Sosyal medya kullanımının kişilerin narsistik yönlerini daha çok artırdığı ve beslediği gözlenmektedir.

İşte yukarıdaki literatür tartışması ışığında, bu araştırmada aşağıdaki hipotezler oluşturulmuştur:

H1. Narsisizm düzeyi, sosyal medya kullanımının pozitif anlamlı yordayıcısıdır.

H2. Narsisizm alt boyutları ile sosyal medya kullanım alt boyutları arasında anlamlı iliş̧i vardır.

H3. Narsisizm düzeyi arttıkça, günlük sosyal medya kullanım süresi de artar.

\section{Yöntem}

$\mathrm{Bu}$ araştırma, Konya merkezde yaşayan 18-65 yaş arası bireylerin oransal olarak, sosyal medya kullanımı ve narsisizm arasındaki ilişkinin doğasını ortaya koymayı amaçlayan betimsel bir çalışmadan oluşmaktadır.

\subsection{Araștırmanın Uygulanması ve Örneklem}

Konya merkezde yaşayan 18-65 yaş arasında sosyal medya kullanan bireylerin narsisizm davranışları arasındaki ilişkiyi belirlemek amacıyla Konya ili merkezi örneğinde bir saha araştırması olarak gerçekleştirilmiştir. Bu nedenle araştırmanın 
evrenini Konya merkezde yaşayan 18-65 yaş arasında sosyal medya kullanan kişiler oluşturmaktadır. 2017 yılı itibariyle Konya'daki sosyal medya kullanıcı sayıları şöyledir: YouTube= 1.213.943; Facebook=1.210.330; Instagram $=972.586$ ve Twitter $=950.973$ (reklamvermek.com).

Örneklemin belirlenmesinde amaçlı örnekleme türlerinden olan kolay ulaşılabilir durum örneklemesi alma tekniği esas alınmıştır. Konya merkezde yaşayan 18-65 yaş arasında sosyal medya kullanan 430 kişiye yüz yüze anket tekniği uygulanmıştır. Ön inceleme sonucunda 408 anket analiz için uygun görülmüştür. Anketlerin geri dönüşüm oranı yüzde 94,8 'dir.

Örneklem, sekiz (8) farklı meslek grubundan oluşan, Konya merkezde yaşayan toplam dört yüz sekiz (408) katılımcıdan oluşmaktadır. Katılımcıların yüzde 51,7'si $(\mathrm{N}=211)$ erkek, yüzde 48,3'ü $(\mathrm{N}=197)$ ise kadın vatandaşlardan oluşmaktadır. Değerlere bakıldığında araştırma sorularına cevap verenlerin cinsiyete göre dağılımın, karşılaştırma yapmaya uygundur.

Araştırmanın katılımcıları en küçük 18, en büyük 63 yaşında bireylerden oluşmaktadır. Örneklemde yer alan katılımcıların yaş ortalaması 30,08'dir.

Katılımcıların medeni durumuna bakıldığında yüzde 56,4'ünün bekâr, yüzde 43,6'sının evli olduğu görülmektedir.

Araştırma sorularına cevap verenlerin yüzde 8,6'sı ilkokul, yüzde 7,4'ü ortaokul, yüzde 33,8'i lise, yüzde 37,5'i üniversite, yüzde 12,7'si lisansüstü eğitime sahiptir.

Katılımcıların mesleklerine bakıldığında ise; yüzde 16,7'sini işçiler, yüzde 15,9'unu memurlar, yüzde 8,1'ini esnaf, yüzde 15,9'unu serbest meslek sahipleri, yüzde 2'sini emekliler, yüzde 1,2'sini sanayici-tüccar, yüzde 9,1'ini ev hanımları ve 31,1 gibi büyük bir çoğunluğunu öğrenciler oluşturmaktadır.

\subsection{Veri Toplama Araçları}

Araştırmaya katılan Konya merkezde yaşayan 18-65 yaş arasındaki bireylerin narsisizm davranışları ve sosyal medya kullanımları arasındaki ilişkiyi ölçmek için, üç bölüm toplam 57 sorudan oluşan bir anket formu hazırlanmıştır. Araştırmada kullanılan anket formunda şu ölçeklerden yararlanılmıştır:

Narsistik Kişilik Envanteri (NKE): İngilizce ismi, "Narcissistic Personality Inventory (NPI)" olan Narsistik Kişilik Envanteri (NKE), Raskin ve Terry (1988) tarafından bireylerin narsisizm düzeylerini ölçmek üzere geliştirdikleri; 6’lı likert tipi (1=Hiç katılmıyorum, 2=Katılmıyorum, 3=Biraz Katılmıyorum, 4=Biraz Katılıyorum, 5=Katılıyorum, 6=Tamamen Katılıyorum) 40 maddeden oluşmaktadır. Ölçekten alınabilecek en yüksek puan 240, en düşük puan 40'dır. Analiz sonuçları ölçeğin yedi boyuttan oluştuğunu ortaya koymuştur. Bu yedi boyut; "üstünlük”, "sömürücülük", "otorite", "kendine yeterlilik", "kendini beğenme", "hak iddia etme" ve "teşhircilik” olarak belirlenmiştir. 
Kubarych ve arkadaşlarının (2004: s.862) çalışmasında ölçeğin güvenilirliği ,85 olarak belirlenmiştir. Bu araştırmada ölçeğin güvenilirlik katsayısı, Cronbach's Alpha= ,93 olarak hesaplanmıştır.

Sosyal Medya Kullanımı Entegrasyon Ölçeği (SMUIS): Sosyal Medya Kullanımı Entegrasyon Ölçeğinin (Social Media Use Integration Scale-SMUIS), orijinal şekli Jenkins-Guarnieri, Wright ve Johnson tarafından 2013 yılında geliştirilmiştir. Ölçek; (1= Hiç Katılmıyorum, 2= Katılmıyorum, 3= Biraz Katılmıyorum, 4= Biraz Katılıyorum, 5= Katılıyorum, 6= Tamamen Katılıyorum olmak üzere), 6'lı likert tipi 10 maddeden oluşmaktadır. Ölçekte 8. Madde (Sosyal medya kullanmayı sevmiyorum) ters kodlanmıştır. Ölçekten alınabilecek en yüksek puan 60, en düşük puan 10'dur. Yüksek puanlar sosyal medya kullanım düzeyinin yükseldiğini göstermektedir. Ölçeğin bütünü için güvenilirlik katsayısı ,91 olarak bulunmuştur. Ölçeğin Türkçe'ye uyarlama çalışması Akın ve arkadaşları (2015) tarafından yapılmıştır. Yazarlar sosyal Medya Kullanımı Ölçeği'nin Cronbach alfa iç tutarlılık güvenirlik kat sayılarını; ölçeğin sosyal bütünleşme ve duygusal bağlantı alt ölçeği için ,87; sosyal rutinlerle bütünleşme alt ölçeği için ,71, ölçeğin bütünü için ,87 olarak tespit etmişlerdir (Akın vd., 2015: s.647). Bu çalışmada ölçeğin güvenilirlik katsayısı, Cronbach's Alpha=, 83 olarak ortaya konulmuştur.

Kişisel Bilgi Formu: Anket formunun son bölümünü oluşturan bu kısımda, katılımcıların yaş, cinsiyet, medeni durum, eğitim düzeyi, mesleği gibi demografik bilgilerin yanı sıra, katılımcıların sosyal medya kullanımlarına yönelik; günlük sosyal medya kullanım süresi, haftalık sosyal medya kullanım sıklığını belirlemeye yönelik sorular bulunmaktadır.

\subsection{Verilerin Analizi ve Kullanılan Testler}

Saha araştırması 20 Kasım - 31 Aralık 2018 tarihleri arasında katılımcılarla yüz yüze görüşülerek yapılmıştır. Görüşme sonucunda elde edilen veriler, istatistik programı kullanılarak analiz edilmiştir. Araştırmada yararlanılan Sosyal Medya Kullanım (Skewness: 0,106; Kurtosis: -0,292) ile Narsisizm (Skewness: -0,331; Kurtosis: 0,170 ) ölçeği için elde edilen Skewness (Çarpıklık) ve Kurtosis (Basıklık) değerleri -2,0 ile +2,0 arasında değiştiğinden; verilerin normal dağılım gösterdiği görülmektedir (George \& Mallery, 2010). Bu sonuçlardan yola çıkarak, verilerin analizinde parametrik testler tercih edilmiştir. Cinsiyete göre Sosyal medya kullanımı amaçları ve narsisizm düzeyinde farklılaşma olup olmadığını ortaya koymak için Bağımsız Örneklem T-Testi kullanılmıştır. Narsisizm boyutları ve sosyal medya kullanımı arasındaki ilişkinin yönünü ve düzeyini belirlemek için Korelasyon Analizine başvurulmuştur. Aynı zamanda katılımcıların narsisizm düzeyinin sosyal medya kullanım amaçları düzeyini yordayıp yordamadığını ortaya koymak adına Doğrusal Regresyon Analizi esas alınmıştır.

\section{Bulgular ve Yorum}

Bu bölümde katılımcıların sosyal medya kullanım alışkanlıkları, narsisizm düzeylerini 
incelemenin yanında örneklemde yer alan bireylerin sosyal medya kullanım alışkanlıkları ile narsisizm düzeyleri arasındaki ilişki incelenmiştir.

\subsection{Sosyal Medya Kullanım Alıșkanlıkları}

Çalışma kapsamında katılımcıların bir oturumda sosyal medyayı ne kadar süre kullandıkları araştırılmıştır. Betimleyici istatistik sonuçları incelendiğinde katılımcıların bir oturumda en az 5, en fazla 1440 dakika sosyal medyayı kullandıkları belirlenmiştir. Katılımcıların ortalama sosyal medya kullanım süresi 173 dakikadır.

Katılımcıların sosyal medyayı haftalık kullanım sıklığına bakıldığında yüzde 9,3'ü haftada 1-2 gün, yüzde 9,6'sı haftada 3-4 gün, yüzde 10,8'i haftada 5-6 gün, yüzde 70,3 'ü her gün düzenli olarak sosyal medyayı kullandığı ortaya konmuştur.

Tablo 1. Sosyal Medya Kullanım Ölçeğinin Betimleyici İstatistikleri

\begin{tabular}{lccccc}
\hline & N & En Az & En Çok & X & SD \\
\hline Sosyal Medya Kullanımı (İndeks) & 408 & 10,00 & 60,00 & 33,18 & 10,84 \\
\hline
\end{tabular}

$\mathrm{Bu}$ araştırma kapsamında sosyal medya kullanım ölçeğinde yer alan 10 madde birleştirilerek (compute edilerek) tek bir değişkene çevrilmiş; söz konusu değişkenin merkezi eğilim istatistikleri mercek altına alınmıştır. Bireylerin sosyal medya kullanım ölçeğindeki maddelere en düşük 10, en yüksek 60 puan verdikleri bulgulanmıştır. Katılımcıların sosyal medya kullanım düzeyinin ortalaması $X=33,18$ 'dir. Dağılımın standart sapması ise 10,84 olarak tespit edilmiştir.

Tablo 2. Cinsiyete Göre Sosyal Medya Kullanım Düzeyindeki Farklılık

\begin{tabular}{cccccc}
\hline & Cinsiyet & N & $\mathbf{X}$ & t-value & Sig. \\
\hline \multirow{2}{*}{ Sosyal Medya Kullanımı (Indeks) } & Kadın & 197 & 32,91 & \multirow{2}{*}{, 490} &, 624 \\
& Erkek & 211 & 33,44 & & \\
\hline
\end{tabular}

Araştırmaya katılanların cinsiyetine göre sosyal medya kullanım düzeyleri anlamlı farlılık göstermemektedir $(t=, 490 ; p>, 05)$. Sonuçlara göre hem kadınlar $(X=32,91)$ hem de erkekler $(X=33,44)$ sosyal medya kullanım davranışı bakımından birbirlerine yakın değerlere sahip oldukları görülmektedir.

Öte yandan katılımcıların sosyal medya kullanım amaçları alt boyutlarını belirlemek üzere, sosyal medya kullanım ölçeğindeki 10 maddeye verilen yanıtlar doğrultusunda faktör analizi uygulanmış; öz değer (eigenvalue) ve yamaç eğrisi grafiği (screeplot) incelemesi sonucunda 2 faktör grubunun ele alınabileceği anlaşılmıştır. Ölçekte yer alan 1 madde gerekli yükleme değerine sahip olmadığı için analiz dışında tutulmuştur. Ölçekte yer alan ifadelerin faktör yükleme değerleri Tablo 3’te sunulmaktadır. 
Tablo 3. Sosyal Medya Kullanım Alt Boyutlarını Belirlemeye Yönelik Faktör Analizi Sonuçları (Principal Component Analysis, VarimaxRotation, $\mathrm{N}=408$ )

\begin{tabular}{lc}
\hline Sosyal Medya Kullanım Alt Boyutları & $\begin{array}{c}\text { Faktör } \\
\text { Yükleme }\end{array}$ \\
\hline 1. Faktör: Sosyal Bütünleşme Ve Duygusal Bağlantı &, 821 \\
3. Kendimi çevremdekilerden eksik hissetmemek için &, 755 \\
4. Kendimi üzgün hissetmemek için &, 729 \\
2. Herkesle iletişim kurmak için &, 642 \\
1. Arkadaşlarımla olan bağımı kopartmamak için &, 625 \\
5. İnsanlarla daha çok sosyal medya aracılığıyla iletişim kurmayı tercih ettiğim için &, 675 \\
2. Faktör: Sosyal Rutinlerle Bütünleşme &, 615 \\
8. Sosyal medya kullanmayı sevmiyorum &, 589 \\
7. Hesaplarımı kontrol etmekten zevk aldığım için &, 499 \\
9. Günlük rutinim haline geldiği için &, 695 \\
10. Başkalarının paylaşımlarına bakmak ve yorum yapmak için &
\end{tabular}

Faktör gruplarının sınıflandırılma ve değerlendirilmesinde Varimax rotasyonlu tablo esas alınmıştır. Faktör analizinde incelenen maddelerin özdeğeri 1'den daha büyük ve minimum yükleme büyüklüğü 0,45 'dir. Faktör analizine dâhil edilen 10 maddenin güvenilirlik katsayısı (Cronbach's $a=, 83$ ) genel olarak tatmin edicidir. Analiz sonucunda ortaya konan boyutlar, sosyal medya kullanımı açısından toplam varyansın yüzde 54,15'ini açıklama kapasitesi sahiptir.

Tablo 4. Sosyal Medya Kullanım Alt Boyutlarının Özdeğeri, Açıklanan Varyansları ve Güvenilirlik Katsayıları

\begin{tabular}{lccc}
\hline Alt Boyutlar & Özdeğer & $\begin{array}{c}\text { Açıklanan } \\
\text { Varyans (\%) }\end{array}$ & $\begin{array}{c}\text { Cronbach's } \\
\text { Alpha (a) }\end{array}$ \\
\hline $\begin{array}{l}\text { Sosyal Bütünleşme Ve Duygusal } \\
\text { Bağlantı }\end{array}$ & 3,74 & 34,75 &, 80 \\
\hline Sosyal Rutinlerle Bütünleşme & 1,13 & 19,40 &, 71 \\
\hline TOPLAM & 54,15 &, 83 \\
\hline KMO Measure of SamplingAdequacy: ,817; Barlett's Test of Sphericity: $\mathrm{X}^{2}=1046,2 ; \mathrm{df}=$ \\
36; $\mathrm{p=}, 000$
\end{tabular}

Faktör analizi tablosuna bakıldığında; insanların sosyal medya kullanmalarında ilk boyut Sosyal Bütünleşme Ve Duygusal Bağlantı'dır. Bu boyutu oluşturan maddeler 
incelendiğinde; kullanıcıların kendilerini eksik ve üzgün hissetmemek, iletişim kurmak ve arkadaşlarla bağı kopartmamak gibi nedenlerle sosyal medyaya yöneldikleri ortaya çıkmaktadır. Sosyal Bütünleşme Ve Duygusal Bağlantı faktörü tek başına toplam varyansın yüzde 34,75'ini açıklamaktadır. Faktörün güvenilirlik (Cronbach's a = ,80) ve özdeğeri (Eigenvalue= 3,74 ) yüksektir.

İkinci boyut, Sosyal Rutinlerle Bütünleşme ismini taşımaktadır. Bu faktörü oluşturan maddeler; hesapları kontrol etmekten zevk alma, günlük rutin içerisinde başkalarının paylaşımlarına bakma ve yorum yapma gibi nedenlerle insanların sosyal medya kullandıklarına işaret etmektedir. Sosyal Rutinlerle Bütünleşme faktörü, tek başına toplam varyansın yüzde 19,40'ını açıklarken; faktörün güvenilirlik (Cronbach's a = ,71) ve özdeğeri (Eigenvalue= 1,13) kabul edilebilir sınırlar içerisinde yer almaktadır (Özdamar, 2004: s.633; Yazıcıoğlu ve Erdoğan, 2004: s.186).

\subsection{Narsisizm Düzeyi}

Araştırmanın bu bölümünde narsisizm ölçeğinde yer alan 40 maddelik değişken hesaplanarak (compute edilerek) tek bir değişkene çevrilmiştir. Betimleyici istatistik analizi ile katılımcıların narsisizm düzeyleri ortaya konulmuştur.

Tablo 5. Narsisizm Düzeyinin Betimleyici İstatistikleri

\begin{tabular}{cccccc}
\hline & N & En Az & En Çok & X & SD \\
\hline Narsisizm Düzeyi (Indeks) & 408 & 49,00 & 240,00 & 156,73 & 32,56 \\
\hline
\end{tabular}

Araştırmaya katılanların narsisizm ölçeğindeki maddelere vermiş oldukları puanlar toplandığında; en düşük 49, en yüksek 240 puana sahip oldukları görülmektedir. Katılımcıların narsisizm düzeyi ortalaması $X=156,73$ 'tür. Dağılımın standart sapması ise 32,56 olarak analiz edilmiştir.

Tablo 6. Narsisizm Boyutlarının Betimleyici İstatistik ve Güvenilirlik Katsayıları

\begin{tabular}{lccccc}
\hline Narsisizm Boyutları & N & En Az & En Çok & X & Cronbach'sAlpha \\
\hline Kendini Beğenme & 408 & 1,00 & 6,00 & 4,26 &, 51 \\
\hline Hak Sahipliği & 408 & 1,00 & 6,00 & 4,19 &, 75 \\
\hline Üstünlük & 408 & 1,00 & 6,00 & 3,80 &, 72 \\
\hline Kendine Yetme & 408 & 1,00 & 6,00 & 3,93 &, 66 \\
\hline Sömürücülük & 408 & 1,00 & 6,00 & 3,85 &, 75 \\
\hline Teşhircilik & 408 & 1,00 & 6,00 & 3,80 &, 58 \\
\hline Otorite & 408 & 1,00 & 6,00 & 3,87 &, 77 \\
\hline Narsisizm (Indeks) & 408 & 49,00 & 240,00 & 156,73 &, 93 \\
\hline
\end{tabular}


Narsisizm düzeyleri boyutlara ayrıldığında, örneklemdeki bireylerin en çok puan verdikleri boyut Kendini Beğenme'dir $(X=4,26)$. Ikinci sırada Hak Sahipliği $(X=4,19)$ boyutu yer almaktadır. En az puan verilenler ise Üstünlük $(X=3,80)$ ve Teşhircilik $(X=$ 3,80 ) boyutları olarak ortaya çıkmaktadır.

Tablo 7. Cinsiyete Göre Narsisizm Boyutlarına Katılımdaki Farklılık

\begin{tabular}{|c|c|c|c|c|c|}
\hline Narsisizm Boyutları & Cinsiyet & $\mathbf{N}$ & $x$ & t-value & Sig. \\
\hline \multirow{2}{*}{ Otorite } & Erkek & 211 & 3,92 & \multirow{2}{*}{1,05} & \multirow{2}{*}{,292 } \\
\hline & Kadın & 197 & 3,81 & & \\
\hline \multirow{2}{*}{ Kendine Yetme } & Erkek & 211 & 3,99 & \multirow{2}{*}{1,26} & \multirow{2}{*}{,208 } \\
\hline & Kadın & 197 & 3,87 & & \\
\hline \multirow{2}{*}{ Üstünlük } & Erkek & 211 & 3,85 & \multirow{2}{*}{,094 } & \multirow{2}{*}{,925 } \\
\hline & Kadın & 197 & 3,84 & & \\
\hline \multirow{2}{*}{ Kendini Beğenme } & Erkek & 211 & 4,20 & \multirow{2}{*}{$-1,13$} & \multirow{2}{*}{,259 } \\
\hline & Kadın & 197 & 4,32 & & \\
\hline \multirow{2}{*}{ Hak Sahipliği } & Erkek & 211 & 4,08 & \multirow{2}{*}{$-2,35$} & \multirow{2}{*}{,019 } \\
\hline & Kadın & 197 & 4,30 & & \\
\hline \multirow{2}{*}{ Teşhircilik } & Erkek & 211 & 3,82 & \multirow{2}{*}{,215 } & \multirow{2}{*}{,830 } \\
\hline & Kadın & 197 & 3,79 & & \\
\hline \multirow{2}{*}{ Sömürücülük } & Erkek & 211 & 3,85 & \multirow{2}{*}{,094 } & \multirow{2}{*}{,925 } \\
\hline & Kadın & 197 & 3,84 & & \\
\hline
\end{tabular}

Araştırmaya katılan bireylerin cinsiyetine göre Hak Sahipliği boyutuna verdikleri puan anlamlı farklılık taşımaktadır $(\mathrm{t}=-2,35 ; \mathrm{p}<, 05)$. Betimleyici istatistik sonuçlarına bakıldığında; kadınların ( $X=4,30)$ Hak Sahipliği boyutunun puan ortalaması, erkeklerden $(X=4,08)$ daha yüksektir.

\subsection{Narsisizm ve Sosyal Medya Kullanımı Arasındaki İlișki}

Araştırmanın bu bölümünde öncelikle kullanıcıların, narsisizm düzeylerinin sosyal medya kullanımını açıklama gücü, Doğrusal Regresyon Analizi ile incelenmiş ve elde edilen bulgular Tablo 8'de sunulmuştur.

Tablo 8. Sosyal Medya Kullanım Amaçları Puanının, Narsisizm Düzeyi Tarafından Yordanmasına Ilişkin Doğrusal Regresyon Analizi Sonuçları

\begin{tabular}{lcccc}
\hline & B & Beta $(\boldsymbol{\beta})$ & $\mathbf{t}$ & Sig. \\
\hline (Sabit) Sosyal Medya Kullanımı (Indeks) & 12,619 & & 5,19 &, 000 \\
\hline Narsisizm (Indeks) &, 131 &, 394 & 8,64 &, 000 \\
\hline $\mathrm{R}^{2}=, 155 ;$ Adjusted $\mathrm{R}^{2}=, 153$ & & & $\mathrm{~F}=74,67 ; \mathrm{df}=1 ; \mathrm{p}=, 000$ \\
\hline
\end{tabular}


Narsisizm düzeyinin bağımsız değişken olarak denkleme sokulması sonucu regresyon katsayısı ,131 olarak tespit edilmiştir. Narsisizm düzeyi, sosyal medya kullanım amaçları puanındaki varyansın yüzde 15,3'ünü açıklama kapasitesine sahiptir. Sosyal medya kullanım düzeyini, narsisizm düzeyinin yordayıp yordamadığına ilişkin $\boldsymbol{\beta}$ ve $\mathbf{t}$ değerleri incelendiğinde; narsisizm düzeyinin $(\beta=, 394 ; p<, 001)$ sosyal medya kullanım puanını pozitif yönde anlamlı biçimde yordadığı ortaya çıkmaktadır. Bu sonuçlarla Hipotez 1 doğrulanmıştır.

Narsisizm ve sosyal medya kullanım amaçları düzeyi arasındaki ilişkinin düzeyini ve yönünü açıklamak için Korelasyon Analizi sonuçları incelendiğinde, iki değişken arasında pozitif yönde orta düzey anlamlı ilişkinin varlığı dikkat çekmektedir $(r=, 394$; $p<, 01$ ). Bir başka ifadeyle bireylerin narsisizm düzeyleri arttıkça sosyal medya kullanım amaç ve isteklerinde de bir artış yaşanmaktadır (bkz., Tablo 9).

Tablo 9. Narsisizm ile Sosyal Medya Kullanım Düzeyi Arasındaki Ilişsi

\begin{tabular}{|c|c|c|c|c|}
\hline \multirow{9}{*}{ 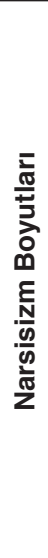 } & & $\begin{array}{l}\text { Sosyal Kullanımı } \\
\text { (Indeks) }\end{array}$ & $\begin{array}{c}\text { Sosyal Bütünleşme } \\
\text { ve Duygusal } \\
\text { Bağlantı }\end{array}$ & $\begin{array}{l}\text { Sosyal Rutinlerle } \\
\text { Bütünleşme }\end{array}$ \\
\hline & Otorite &, $363^{\star *}$ &, $364^{\star *}$ &, $274^{* *}$ \\
\hline & Kendine Yetme &, $248^{\star *}$ &, $262^{* *}$ &, $162^{\star \star}$ \\
\hline & Üstünlük &, $400^{\star \star}$ &, $399^{\star *}$ &, $301^{\star *}$ \\
\hline & Teşhircilik &, $340^{\star \star}$ &, $363^{\star \star}$ &, $223^{\star *}$ \\
\hline & Sömürücülük &, $321^{\star *}$ &, $316^{\star *}$ &, $241^{* *}$ \\
\hline & Kendini Beğenme &, $338^{\star *}$ &, $322^{* *}$ &, $267^{\star *}$ \\
\hline & Hak Sahipliği &, $328^{* *}$ &, $314^{\star *}$ & ,260** \\
\hline & Narsisizm (İndeks) & $394^{* *}$ & $394^{\star *}$ & $287^{* *}$ \\
\hline
\end{tabular}

Not: **Correlation is significant at the 0.01 level (2-tailed).

Narsisizm boyutları ile sosyal medya kullanım amaçları arasındaki ilişki incelendiğinde; sosyal medya kullanımı ile otorite $(r=, 363 ; \mathrm{p}<, 01)$, kendine yetme $(r=, 248 ; \mathrm{p}<, 01)$, üstünlük ( $r=, 400 ; \mathrm{p}<, 01)$, kendini beğenme $(r=, 338 ; \mathrm{p}<, 01)$, hak sahipliği $(r=, 328 ; \mathrm{p}<$ $, 01)$, teşhircilik $(r=, 340 ; p<, 01)$ ve sömürücülük $(r=, 321 ; p<, 01)$ alt boyutları arasında pozitif düzeyde anlamlı ilişki bulunmaktadır.

Sosyal Bütünleşme Ve Duygusal Bağlantı faktörü ile otorite $(r=, 364 ; \mathrm{p}<, 01)$ ve üstünlük $(r=, 399 ; \mathrm{p}<, 01)$ alt boyutları arasında orta düzey; diğer boyutlar arasında ise zayıf düzey pozitif anlamlı korelasyon olduğu söylenebilir. Sosyal Rutinlerle Bütünleşme faktörü ile narsisizm boyutları arasında da pozitif yönlü zayıf düzey anlamlı ilişki tespit edilmiştir. Bu sonuçlar Hipotez 2'nin doğrulandığına işaret etmektedir. 
Tablo 10. Narsisizm ile Sosyal Medya Kullanım Süresi Arasındaki Ilişki

Narsisizm (Indeks)

Sosyal Medya Kullanım Süresi

$136^{\star *}$

Not: ${ }^{* \star}$ Correlation is significant at the 0.01 level (2-tailed).

Son olarak sosyal medya kullanım süresi ile narsisizm arasındaki ilişkinin düzeyi ve yönü açısından Korelasyon Analizi sonuçları mercek altına alındığında; iki değişken arasında pozitif zayıf düzey anlamlı ilişki ortaya çıkmaktadır $(r=, 136 ; p<, 01)$. Diğer bir ifadeyle narsisizm düzeyi arttıkça günlük sosyal medya kullanım süresinde de bir artış yaşanmaktadır. Burada ortaya çıkan sonuçlarla; Hipotez 3 doğrulanmıştır.

\section{Sonuç ve Tartıșma}

Günümüzde sosyal medya, narsisizm eğilimlerine uyabilecek iletişim özellikleri göstermesi bakımından önemli bir araçtır. Böyle bir önemin ortaya çıkmasında ilk olarak, sosyal medyanın çok sayıda başka kişiye kolay erişim sağlaması etkili olabilmektedir. Kullanıcılar kendileriyle ilgili bilgileri geniş bir kitleye gönderme ve kendi hakkında ve diğerleriyle ilgili bilgi alma şansına sahiptir. İkinci olarak, kullanıcılar kendileri hakkında açığa vurdukları bilgileri seçebilirler. Başarıları ve üstünlükleri iletmek için resim ve kelimeler kullanabilirler (böylece, kendi yapılarına uymayan olayları görmezden gelirler). Üçüncüsü, sosyal medyada iletişimin asenkronikliği, kullanıcılara kendi sunumlarını titizlikle yapma fırsatı verir. Bireyler sosyal medya hesapları üzerinden içerikler paylaşarak, mevcut platformda var olan arkadaşlarının tepki vermelerini kolaylaştırabilir (Gnambs ve Appel, 2018: s.201). Bu sayede kişi bir anlamda varlığını dünyaya bildirmektedir ( Hogg ve Vaughan, 2014: s.153). Narsistik karakter özelliklerinin kolaylıkla sergilendiği sosyal medya, gündelik yaşamda kolaylıkla sergilenemeyecek karakter özelliklerinin, rahat ve kısa sürede çok fazla kişiye ulaştırılması olanağı sunarak, narsisizm duygusunun daha çok tetiklenmesine (Oğuz, 2016: s.64) ve söz konusu isteğin beraberinde sosyal medyaya yönelimi artıracağını söyleyebiliriz.

Söz konusu düşüncelerden yola çıkılarak, Konya örneğinde bir saha araştırması gerçekleştirilmiştir. Araştırma bulguları; örneklemdeki bireylerin günlük ortalama sosyal medya kullanım süresinin 173 dakika olduğuna işaret etmektedir. Katılımcıların yüzde 70,3 gibi önemli bir kısmı, her gün düzenli sosyal medya kullandığını dile getirmektedir. Burada ortaya çıkan sonuçlar, Durak ve Seferoğlu'nun (2016: s.533) araştırmasıyla örtüşmektedir. Yazarların vurguladığı üzere, Türkiye'de sosyal medyanın günlük kullanım süresi ortalama 3 saattir. Türkiye'de özellikle gençlerin çok büyük bir çoğunluğu, sosyal medyaya günde en az bir kere bağlanmaktadır. Ayrıca Türkiye'de sadece gençlerin değil ebeveynlerin de sosyal medya kullanımının önemli oranda olduğu söylenebilir. Sosyal medya kullanımı açısından kadınların ve erkeklerin ortalama puanları birbirlerine yakındır. Sosyal medya alt boyutları içeresinde Sosyal Bütünleşme ve Duygusal Bağlantı daha çok ön plana çıkan boyutu oluşturmaktadır. Diğer bir ifadeyle; kullanıcılar, kendilerini eksik ve üzgün hissetmemek, iletişim 
kurmak ve arkadaşlarla bağı kopartmamak gibi nedenlerle sosyal medyaya daha çok yönelmektedirler.

Öte yandan katılımcıların narsisizm puanlarının orta düzeyde olduğunu söyleyebilir. Narsisizm alt boyutları arasında katılımcıların en çok puan verdiği boyut Kendini Beğenme; en az puan verdikleri boyutlar ise Teşhircilik ve Üstünlük’tür. Narsisizm boyutları ile cinsiyet arasında Hak Sahipliği boyutunda anlamlı farlılık gözlenmiştir. Kadınların, Hak Sahipliği boyutuna verdikleri puan ortalaması erkeklerden daha fazla olduğu tespit edilmiştir.

Narsisizmin sosyal medya kullanım davranışını pozitif yönde yordadığı, bu araştırmada ortaya konulmuştur. Araştırma sorularına cevap verenlerin narsisizm puanları arttıkça, sosyal medya kullanım amaçlarında bir artış yaşanmaktadır. Öyle ki; bireylerin "çevresini etkileyen doğal bir yeteneğe sahip birisi olduğuna inanması; kendisini iyi bir lider gibi görme, iddialı biri olduğumu düşünme, diğer insanlar üzerinde otorite kurmayı isteme, kendisine saygı duyulmasında ısrarcı olma, karar vermek için sorumluluk alma, bakımlı olmayı sevme, kendi hikâyesini dinletmekten hoşlanma, ilgi odağı olmayı isteme, sıra dışı biri olduğunu düşünme" vb. gibi eğilimlerindeki artış, beraberinde bu özellikleri yansıtmada önemli açılımlar sağlayan sosyal medyaya yönelimi artırabilmektedir. Narsisizm düzeyi yüksek olan bireyler sosyal medyada daha çok durum güncellemesi yapmakta ve kendi fotoğraflarını daha sık yayınlamaktadır. Daha önceki araştırmalarda (Leung, 2013; Kuss ve Griffiths, 2011; Correa vd., 2010) da narsisizm gibi kişilik özelliğinin, sosyal medya davranışını etkileyen önemli faktör olduğu bulgulanmıştır. Sosyal medyanın kendini ifade etme ve gösterme yönünde kullanıcılarına sağladığı ayrıcalık, özellikle narsisizm özelliği belirgin kişileri bu araçlara yönelme konusunda cesaretlendirmektedir. Yine otorite, kendine yetme, üstünlük, teşhircilik, sömürücülük, kendine beğenme ve hak sahipliği yönelimli narsisizm düzeyi arttıkça, sosyal medya kullanım amaçlarında da bir artış kendini gösterebilmektedir. Benzer şekilde örneklemdeki bireylerin narsisizm düzeylerinin artması, günlük sosyal medya kullanım süresini de artırmaktadır.

Son söz olarak bu çalışma; Türkiye'de sosyal medya kullanım amaçları ile narsisizm arasındaki ilişkinin doğasını ışık tutmaya çalışan az sayıdaki bilimsel girişimlerden birisi konumundadır. Bu noktada ülkenin farklı bölgelerinde yapılacak araştırmalar, hem ulusal literatürün zenginleşmesi hem de karşılaştırmalar yapmak açısından önem taşımaktadır. Bu çalışmada toplumun farklı sosyo demografik özelliklerine sahip kesimleri örneklenmiştir. Gelecekteki çalışmalar yaş etkilerini ve genç ergen sosyal medya kullanıcılarının narsistik özelliklerini daha fazla araştırmak isteyebilir. Söz konusu araştırmada bir bütün olarak sosyal medya kullanımı mercek altına alınmıştır. Gelecekteki araştırmalar sosyal medya araçları olarak Instagram, Facebook, WhatsApp vb. ile narsisizm arasındaki ilişkiyi inceleyebilirler. Yine gelecekteki araştırmalar, sosyal medya kullanımıyla daha güçlü bir ilişkiye sahip olabilecek diğer kişisel özellikleri (yalnızlık, benlik sunumu, öz saygı, kendini açma ve kendini gizleme vb.) inceleyerek, mevcut araştırmada ortaya çıkan bazı eksikliklere ışık tutabilir. 


\section{Kaynakça}

Abdullah, M. C.,Ling, L. M., and Roslan, S. (2014). Narcissism as Predictor of Facebook Usage among Students in a Malaysian Public University. In A. Kasim et al. (Eds.), Proceedings of the International Conference on Science, Technology and Social Sciences 2012 (pp. 51-61). Singapore: Springer.

Akın, A., Özbay, A., ve Baykut, ì. (2015). Sosyal Medya Kullanımı Ölçeği'nin Türkçe Formu'nun Geçerliği Ve Güvenirliği. Uluslararası Sosyal Araştırmalar Dergisi, 8 (38), 647-652.

Alanka, Ö. Ve Cezik, A. (2016). Dijital Kibir: Sosyal Medyadaki Narsistik Ritüellere Ilişkin Bir İnceleme, TRT Akademi: Dijital Medya Sayısı, 1(2), 548-569.

Alemdar, M. Y. and Köker, N. E. (2013). Facebook Use And Gratifications: A Study Directed to Determining the Facebook Usage of Generations $X$ and $Y$ in Turkey. Mediterranean Journal of Social Sciences. 4(11), 238-249.

Alemdar, M. Y., İşbilen, D., Demirel, K. ve Telli, N. G (2017). Özçekim Davranışı Narsisizm Göstergesi Olabilir Mi? Özçekim ve Narsisizm Arasındaki Ilişkiyi Tanımlamaya Yönelik Nitel Bir Araştırma, Global Medya Journal TR, 8(15), 71-97.

Barry, C. T., Doucette, H., Loflin, D. C., Rivera-Hudson, N., and Herrington, L. L. (2017). "Let me take a selfie": Associations between self-photography, narcissism, and self-esteem. Psychology of Popular Media Culture, 6(1), 48-60.

Bergman, S. M., Fearrington, M. E., Davenport, S. W., and Bergman, J. Z. (2011). Millennials, Narcissism and Social Networking: What Narcissists Do on Social Networking Sites and Why. Personality and Individual Differences, 50, 706-711.

Buffardi, L. E. and Campbel, W. K. (2008). Narcissism and Social Networking Web Sites. Personality and Social Psychology Bulletin, 34, 1303-1314.

Çakmak, V. (2018). Online Benlik Sunumu ve Narsisizm Arasındaki İlişki: Üniversite Öğrencileri Üzerinde Bir Araştırma. AJIT-e: Online Academic Journal of Information Technology, 9(30), 137152.

Carpenter, C. J. (2012). Narcissism on Facebook: Self-promotional and anti-social behavior. Personality and Individual Differences, 52, 482-486.

Correa, T., Hinsley, A. W., and De Zuniga, H. G. (2010). Who interacts on the web? The intersection of users' personality and social media use. Computers in Human Behavior, 26(2), 247-253.

Davenport, S.W., Bergman, S. M., Bergman, J. Z. and Fearrington, M. E. (2014). Twitter versus Facebook: Exploring the role of Narcissism in the Motives and Usage of Different Social Media Platforms. Computers in Human Behavior, 32, 212-220.

Durak, H. ve Seferoğlu, S. S. (2016). Türkiye'de Sosyal Medya Okuryazarlığı Ve Sosyal Ağ Kullanım Örüntülerinin İncelenmesi. Uluslararası Sosyal Araştırmalar Dergisi, 9(46), 526-535.

Ekşi, F. (2012). Narsist Kişilik Özelliklerinin İnternet Bağımlılı̆ı Ve Siber Zorbalığı Yordama Düzeyinin Yol Analizi İle İncelenmesi. Kuram Ve Uygulamada Eğitim Bilimleri. 12(3), 1683-1706.

Ertürk, Y. D. Ve Eray, T. E. (2016). Fenomenolojik Bir Kavram Olarak Kendilik Ve Sosyal Ağlarda 
Kendilik Sunumu İle Narsistik Eğilimler İlişkisi: İletişim Fakültesi (İ.Ü.I..F.) Öğrencileri Üzerine Bir Ön Çalışma, Intermedia International e-Journal, 3(1), $12-29$.

Fox, J. and Rooney, M. C. (2015). The Dark Triad and Trait Self-Objectification as Predictors of Men's Use and Self-Presentation Behaviors on Social Networking Sites. Personality and Individual Differences, 76, 161-165.

Freud, S. (1998). Narsisizm Üzerine ve Schreber Vakası, Banu Büyükkal ve Saffet Murat Tura (Çev.), İstanbul: Metis Yayıncılık.

Gençtan, E. (2010). Psikodinamik Psikiyatri ve Normaldışı Davranışlar. Ankara: Remzi Kitapevi.

George, D. and Mallery, P. (2010).SPSS for Windows Step by Step: A Simple Guide and Reference 17.0 Update (10th Edition b.). Boston: Pearson.

Gnambs, T., and Appel, M. (2018). Narcissism and Social Networking Behavior: A Meta-Analysis. Journal of Personality, 86(2), 200-212.

Gülnar, B., Balcı, Ş. and Çakır, V. (2010). Motivations of Facebook, YouTube and Similar Web Sites Users. Bilig Journal of Social Sciences of the Turkish World, 54,161- 184.

Hogg, M. A. ve Vaughan, G. M. (2014): Sosyal Psikoloji, 2. Baskı, Ankara, Ütopya Yayınevi.

https://reklamvermek.com/upload/24/turkiye-internet-kullanim-oranlari.pdf, (Erişim: 20 Nisan 2019)

Huang, H. (2014). Social Media Generation in Urban China. Berlin, Germany: Springer.

Jenkins-Guarnieri, M. A., Wright, S. L., and Johnson, B. (2013). Development and Validation of a Social Media Use İntegration Scale. Psychology of Popular Media Culture, 2(1), 38-50.

Kaplan, A. M. and Haenlein M. (2010). "Users Of The World, Unite! The Challenges and Opportunities of Social Media", Business Horizons, 53(1), 59-68.

Köseoğlu, Ö. (2012). Sosyal Ağ Sitesi Kullanıcılarının Motivasyonları: Facebook Üzerine Bir Araştırma, Selçuk Iletişim, 7(2), 52-81.

Kubarych, T. S., Deary, I. J., Austin, E. J. (2004). The Narcissistic Personality Inventory: factor structure in a non-clinical sample. Personality and Individual Differences, 36, 857-872.

Kuşay, Y. (2013). Sosyal Medya Ortamında Çekicilik ve Bağımılık. 1. Basım, İstanbul: Beta Basım Yayım Dağıtım.

Kuss, D. J. and Griffiths, M. D. (2011). Online Social Networking and Addiction- A Review of the Psychological Literature. International Journal of Environmental Research and Public Health, 8(9), 3528-3552.

Lee, E., Ahn, J., and Kim, Y. J. (2014). Personality Traits and Self-Presentation at Facebook. Personality and Individual Differences, 69, 162-167.

Leung, L. (2013). Generational Differences in Content Generation in Social Media: The Roles of the Gratifications Sought and of Narcissism. Computers in Human Behavior, 29(3), 997-1006.

Malik, S. and Khan, M. (2015). Impact of Facebook Addiction on Narcissistic Behavior and SelfEsteem among Students. Journal of Pakistan Medical Association, 65, 260-263. 
Marshall, T.C., Lefringhausen, K., and Ferenczi, N. (2015).The Big Five, Self-Esteem, and Narcissism as Predictors of the Topics People Write about in Facebook Status Updates. Personality and Individual Differences, 85, 35-40.

McKinney, B. C., Kelly, L., and Duran, R. L. (2012). Narcissism Or Openness?: College Students' Use Of Facebook And Twitter. Communication Research Reports, 29, 108-118.

Mehdizadeh, S. (2010). Self-Presentation 2.0: Narcissism and Self-Esteem on Facebook, Cyberpsychology, Behaviour and Social Networking, 13(4), 357-364.

Mo, R., and Leung, L. (2015).Exploring the Roles of Narcissism, Gratifications of Microblog Use, and Affinity- Seeking on Social Capital. Asian Journal of Social Psychology, 18(2), 152-162.

Narsisizm,http://www.tdk.gov.tr/?option=com_karsilik\&view=karsilik\&kategori1=abecesel\&kelime 2=N, (Erişim: 02 Ocak 2019).

Nevils, B. and Massie, R. (2014). The Relationship between Social Network Usage and Narcissism. Hanover College, PSY 344: Social Psychology.

Oğuz, T. (2016). Çağdaş Narkisisos'lar: Facebook Kullanım Alışkanlıkları ve Narsisizm, Selçuk Iletişim, 9(2), 51-68

Ong, E. Y., Ang, R. P., Ho, J. C., Lim, J. C., Goh, D. H., Lee, C. S., and Chua, A. Y. (2011). Narcissism, Extraversion and Adolescents' Self- Presentation on Facebook. Personality and Individual Differences, 50(2), 180-185.

Özdamar, K. (2004). Paket Programlar Ile İstatistiksel Veri Analizi. Eskişehir: Kaan Kitabevi.

Özsoy, E. ve Ardıç, K. (2017). Karanlık Üçlünün (Narsisizm, Makyavelizm ve Psikopati) İş Tatminine Etkisinin İncelenmesi, Yönetim ve Ekonomi, 391-406.

Panek, E. T., Nardis, Y., and Konrath, S. (2013). Mirror or Mega Phone? How Relationships between Narcissism and Social Net Working Site Use Differ on Facebook and Twitter. Computers in Human Behavior, 29, 2004-2012.

Pettijohn, T. F. II, LaPiene, K. E., Pettijohn, T. F., and Horting, A. L. (2012). Relationships between Facebook İntensity, Friendship Contingent Self-Esteem, and Personality İn U.S. College Students. Cyberpsychology, 6, 1-7.

Poon, D. C. H., and Leung, L. (2011). Effects Of Narcissism, Leisure Boredom And Gratification Sought On Net- Generation User- Generated Content. International Journal of Cyber Behavior, Psychology \& Learning, 1(3), 1-14.

Raskin, R. and Terry, H. (1988). A Principal-Component Analysis of the Narcissistic Personality Inventory and Further Evidence of its Construct Validity. Journal of Personality and Social Psychology, 54(5), 890-902.

Ryan, T., and Xenos, S. (2011). Who uses Facebook? An investigation into the relationship between the Big Five, shyness, narcissism, loneliness, and Facebook usage. Computers in Human Behavior, 27, 1658-1664.

Sandler, J., Fonagy, P. and Person, E. S. (2012). Freud's On Narcissism: An Introduction. London: Karnac Books. 
Skues, J. L., Williams, B., and Wise, L. (2012). The effects of personality traits, self-esteem, loneliness, and narcissism on Facebook use among university students. Computers in Human Behavior, 28, 2414-2419.

Timuroğlu, K. ve İşcan, F. Ö. (2008). İş Yerinde Narsisizm ve İş Tatmini, iktisadi ve İdari Bilimler Dergisi,22(2), 240-264.

Uçar, M. E. ve Konal, B. (2018). Öğretmenler ile Lise ve Üniversite Öğrencilerindeki Narsisizm Kişilik Özellikleri Benlik Saygısı ve Duygu Gereksinimi Arasındaki Ilişsiler, Uluslararası Toplum Araştırmaları Dergisi, 8(14), 93-136.

Walters, N. T., and Horton, R. (2015). A Diary Study of the İnfluence of Facebook Use on Narcissism among Male College Students. Computers in Human Behavior, 52, 326-330.

Wang, J.-L., Jackson, L. A., Zhang, D.-J., \& Su, Z.-Q. (2012). The relationships among the Big Five personality factors, self-esteem, narcissism, and sensation-seeking to Chinese university students' uses of social networking sites (SNSs). Computers in Human Behavior, 28, 2313-2319. Weiser, E. B. (2015). \# Me: Narcissism and Its Facets as Predictors of Selfie-Posting Frequency. Personality and Individual Differences, 86, 477-481.

Wilson, K., Fornasier, S., and White, K. M. (2010). Psychological Predictors of Young Adults' Use of Social Networking Sites. CyberPsychology, Behavior and Social Networking, 13(2), 173-177.

Winter, S., Neubaum, G., Eimler, S. C., Gordon, V., Theil, J., Herrmann, J., and Krämer, N. C. (2014). Another Brick in the Facebook Wall: How Personality Traits Relate to the Content of Status Updates. Computers in Human Behavior, 34, 194-202.

Yazıcıoğlu, Y. \& Erdoğan, S. (2004). SPSS Uygulamalı Bilimsel Araştırma Yöntemleri. Ankara: Detay Yayıncılık. 